\title{
Representações literárias da escola
}

\author{
MARCUS VINICIUS MAZZARI
}

A montanha do colégı, C. D de Andrade

Um $A B C$ do terror, R. M Rilké

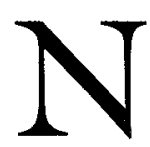

O FINAL DO SEGUNDO capítulo do romance O Ateneu, de Raul Pompéia, o eu-narrador Sérgio condensa as impressões de seu primeiro dia como aluno interno num sonho que parece constituir-se, ao mesmo tempo, em premonição da realidade em que acaba de ingressar: "A mınha aula, o colégio inteiro, mil colégios, arrebatados, num pé-de-vento, voavam léguas afora por uma planície sem termo. Gritavam todos, urravam a sabatina de tabuadas, com um entusiasmo de turbilhão. O pó crescia em nuvens do solo; a massa confusa ouriçava-se de gestos, gestos de galho sem folhas em tormenta agoniada de inverno". Um sonho, portanto, de esmagamento, como se patenteia nos trechos finais: "E eu caía, único vencido! E o tropel, de volta, vinha sobre mim, todos sobre mim! Sopeavam-me, calcavam-me, pesados, carregando prêmios, prêmios aos cestos!".

Delineando-se assim, nas palavras do próprio narrador, a possibilidade de extrapolação para uma dimensão mais geral de "mil colégios", não seria fora de propósito tomar as imagens crispadas e expressionistas desse pesadelo como emblemáticas para uma série de obras que, direta ou indiretamente, tematizam o embate do adolescente ou pré-adolescente com o meio fechado e adverso da escola. "O tempo da adolescência colegial é por certo um dos grandes dramas da formação do indivíduo e isso atrai os romancistas", observa Mário de Andrade em seu ensaio de 1941 sobre $O$ Ateneu (1), e exemplifica a observação citando José Lins do Rego e Otávio de Faria, assim como os franceses Jules Vallès e Gabriel Chevallier. Considerações específicas sobre os vínculos de Pompéia com a cultura francesa faz Leyla Perrone-Moisés num ensaio de aproximação pontual entre $O$ Ateneu e Os cantos de Maldoror, de Lautréamont. A fixação narrativa de um trauma cultural estaria na base de ambas as obras, e embora ressaltando a diferença de tom entre a crônica de saudades de Pompéia e o febril extravasamento de ódio no livro de Lautréamont, em que aliás o tema do internato desponta apenas perifericamente, a autora não deıxa de registrar "um clima nitidamente maldoriano" nas imagens pesadelares de Sérgio (2).

Mas talvez seja na prosa alemã por volta de 1900 que o tema da escola se configura, com intensidade exemplar, sob as formas ouriçadas de pesadelo esmaga- 
dor (3). E é mesmo com surpreendente acúmulo de mortes de colegiais que se reflete aí o advento do que então se chamou "o século da criança", conforme se lê num ensaio de Robert Minder dedicado à representação literária da "escola de cadetes" (4). Como que preludiando essa tendência, o escritor suíço Conrad Ferdinand Meyer publica, em 1883, uma novela com o simples e inequívoco título Das Leiden eines Knaben ( $O$ sofrimento de um menino); o substrato autobiográfico característico das narrativas desse tipo recebe aqui uma camuflagem histórica, na medida em que Meyer situa na França de Luis XIV, em instituição jesuítica militarmente organizada, o drama do menino Julian Boufflers, submetido a torturas sutis que o levam à morte.

Já no romance Unterm Rad (1906), de Hermann Hesse, o herói colegial busca a morte nas águas de um rio, após noite de bebedeira, para subtrair-se à pressão do meio (5). O recurso do suicídio, porém através de arma de fogo e por enforcamento, verifica-se ainda em dois outros romances contemporâneos: Freund Hein (1902), de Emil Strauss, e Mao (1907), de Friedrich Huch.

Neste espaço de cinco anos delimitado pelas publicações acima mencionadas, o austríaco Robert Musil (1880-1942) escreve e publica o romance Die Verwirrungen des Zoglings Torless, amplamente baseado em suas vivências de aluno interno em Eisenstadt e, sobretudo, Mährisch-Weisskirchen (6), onde ingressa em 1894, dois anos após Rainer Maria Rilke (1875-1926) ter encerrado nesta mesma instituição sua experiência traumática de internato $(7)$.

Em apontamentos autobiográficos sobre a gênese do Torless, Musil refere-se a uma intenção inicial de passar o respectivo "assunto" a dois autores naturalistas de seu círculo de relações. Julgava carecer dos meios estéticos adequados para retratar acontecimentos escabrosos num internato masculino, demolidores de toda concepção fundada na "pureza da juventude". Não se concretizando, porém, a "doação", o próprio ex-interno, durante estudos de ciências exatas na Universidade de Stuttgart, põe-se a redigir o romance - para fugir ao "tédio" dos momentos de folga, acrescenta Musil. A alegada inaptidão naturalista do jovem escritor é contornada na medida em que faz a estrutura coercitiva experimentada em Weisskirchen deslocar-se sistematicamente das circunstâncias exteriores para a interioridade das personagens. Decorre daí que o instituto educacional caracterizado no romance pouco corresponde àquele que Musil, décadas depois, irá registrar em seu diário como "diabólico", em que os internos eram tratados como penitenciários (8). Em compensação, no exclusivo e famoso "internato em W.", com seu aspecto feudal propício "para proteger a juventude das influências corruptoras de uma grande cidade" (p. 8), existe a "câmara vermelha" que, enquanto cenário de torturas sádicas, excederá em muito a sombria "cafua" do Ateneu. É o espaço dominado por Reiting e Beineberg, nos quais seu criador, fugindo então do nacional-socialismo, reconhecerá os precursores dos "ditadores atuais" (9).

Mesmo sem partilhar da consideração algo exagerada do Törless como "o livro mais premonitório escrito antes da Primeira Guerra Mundial" (10), a retros- 
pectiva histórica poderá demonstrar aqui, exemplarmente, que o tema em questão não se esgota de forma alguma na mera representação de "um dos grandes dramas da formação do indivíduo", por mais graves e significativos que estes possam ser.

Entre a publicação dos romances $O$ Ateneu e $O$ jovem Törless medeiam 18 anos, espaço de tempo que, em termos de "história cultural", como observa Leyla Perrone-Moisés no ensaio mencionado, pouco significa. Da mesma forma, as várias diferenças estilísticas, ideológicas, culturais que se possam detectar entre essas duas obras contemporaneas revelam-se insuficientes para inviabilizar a abordagem comparativa. Pelo contrário: uma vez que o tema do internato oferece fundamentos efetivos para a aproximação, espera-se que as diferenças constituam planos de contraste ensejando que características específicas de cada obra se ressaltem com maior nitidez. Dessa forma, a perspectiva comparativa e diferencial poderá propiciar compreensão mais aprofundada e matizada da representação literária do embate do adolescente ou pré-adolescente com o mundo da escola.

\section{O Ateneu e O jovem Törless}

"Histórias de internos ou alunos" - em nossa literatura, encontraremos outro representante desse "gênero" no Doidinho, de José Lins do Rego (11) - gravitam em torno de uma constelação cujos contornos podem ser mapeados a partir de alguns pontos fundamentais:

- perda da proteção familiar e ingresso num cotidiano de lutas e desafios acirrados;

- contato com amplo espectro de tipos humanos, que vai do tirano mais implacável ao inevitável bode expiatório;

- intensificação da crise da puberdade em um meio que impossibilita qualquer orientação mais segura;

- relação conflitiva da sensibilidade e consciência crítica emergentes com formas autoritárias de transmissão do saber.

O Ateneu e $O$ jovem Törless não divergem substancialmente desse esquema geral, embora traços básicos do gênero recebam tratamento diferenciado na crônica de saudades pompeiana, articulada em primeira pessoa, e na narrativa onisciente, em terceira pessoa, do romance musiliano. As posições dos narradores não se distinguem, porém, apenas por questões técnicas: enquanto o Sérgio adulto se revela traumaticamente afetado pelas vivências do menino interno no Ateneu (o que engendra, na visão de críticos, o desejo de "vingança pessoal" ou a disposição de "nada perdoar"), o narrador de Musil assume por vezes, saltando para um plano futuro, a perspectiva do Törless adulto, artista amadurecido que soube superar de maneira fecunda as atribulações da adolescência.

A agressão caricaturizante à cultura retórica, encarnada magistralmente por Aristarco, é um fulcro central de $O$ Ateneu, constituindo-se não raro em crítica 
ideológica explícita (embora também impregnada de retórica); pelo lado do romance austríaco, abre-se largo espaço a indagações matemático-filosóficas, as quais remetem a uma formação intelectual que, por ocasião da publicação do romance, encontrava-se sob o influxo da teoria de Ernst Mach sobre o significado dos sentimentos como fonte e base primeira de todo conhecimento. As atribulações de Törless - em muitos aspectos, legítimo precursor do matemático Ulrich, o bomem sem qualidades (12) - problematizam-se sobremaneira após as tentativas frustradas de compreender sensorialmente noções de infinito e de números imaginários, inculcadas nos alunos como dogmas científicos, e a subsequiente destruição das ilusões depositadas no estudo da obra kantiana.

\section{O trauma inicial}

Para além das especificidades de cada obra, os enredos tocam-se em vários pontos, séndo que o primeiro deles é aquele que costuma assinalar o início das histórias desse tipo: permuta do aconchego familiar por um meio que, sedutor à imaginação ingênua, muito depressa revela-se como realidade opressora. Alfredo Bosi fala do ingresso de Sérgio no internato como "trauma da socialização", que talvez em nenhum outro romance de língua portuguesa "se haja intuído com tanta agudeza e ressentido com tanta força" como em O Ateneu de Pompéia (13). Com Theodor W. Adorno, seria possível avançar um pouco mais e enxergar aí o momento em que a criança sai das relações imediatas e protetoras da primary community para experimentar de chofre o que seria quase "o protótipo da própria alienação social" (14).

A magnitude desse corte existencial transparece plenamente no quinto capítulo d' O Ateneu, quando o narrador descreve os sentimentos que o acompanharam em seu primeiro retorno ao lar: "Quando tornei a ver os meus, foi como se os houvesse adquirido de uma ressurreição milagrosa. Entrei em casa desfeito em pranto, dominado pela exuberância de uma alegria mortal. Surpreendiame a ventura incrivel de mirar-me ainda nos olhos queridos, depois da eternidade cruel de duas semanas" (15). Mas já no início da crônica de saudades, em sequiência à fatídica advertência do pai, Sérgio, em amarga antecipação narrativa, atribui ao "regime do amor doméstico", ao "poema dos cuidados maternais", a função única e paradoxal de tornar mais doloroso esse primeiro contato com a instituição social da escola.

Também Musil vale-se de antecipação narrativa para falar de chofre nas "muitas lágrimas" que custara a decisão de ceder à ambição de Törless

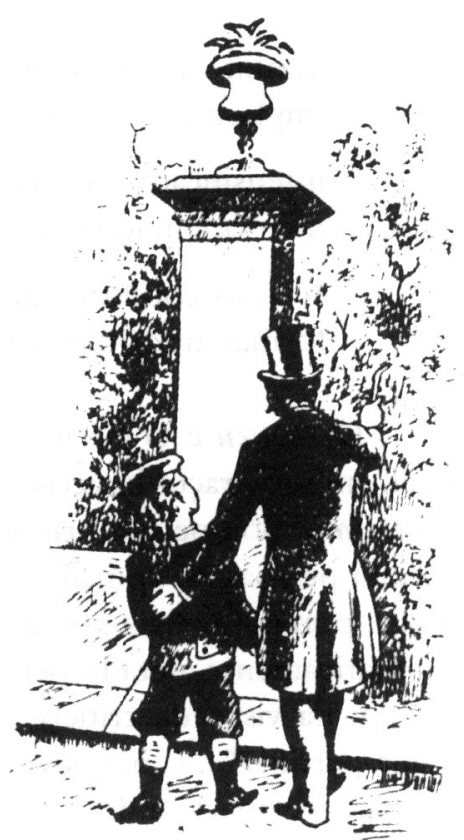

"Vats encontrar o mundo, disse-me meu pai, à porta do Ateneu.Coragem para a luta." 
e enviá-lo ao afamado internato em W., "onde se educavam os filhos das melhores famílias do país". E uma "terrível e apaixonada saudade de casa" que marca os primeiros momentos do menino na nova realidade: "Via tudo como por trás de um véu; mesmo durante o dia, não poucas vezes custava-lhe conter os soluços; à noite, só adormecia chorando" (p. 9). Törless passa a viver apenas nas cartas que escreve diariamente aos pais, e o desdobramento narrativo desse estado emocional enseja o esboço de uma psicologia da nostalgia: refluindo aos poucos a imagem dos pais, em seu lugar vai se insinuando, difusa e indistintamente, uma segunda realidade. Desamparo e vazio interior são os sentimentos característicos dessa fase que, aliás, encontra correspondência na trajetória de Sérgio: "Depois que sacudi fora a tranca dos ideais ingênuos, sentia-me vazio de ânimo; nunca percebi tanto a espiritualidade imponderável da alma: o vácuo habitava-me dentro" (p. 34). Mas se Tórless não adquire clareza sobre esse intrincado processo psíquico, conseguirá ao menos compreender a saudade como algo positivo, uma força espiritual que se manifesta sob a forma de sofrimento. Isto, contudo, somente após a extinção em seu íntimo desse sentimento, e encontrar-se "empobrecido e nu, como uma arvorezinha que experimenta o primeiro inverno após uma floração ainda sem frutos" (p. 10).

\section{$A$ arena do colégio}

Se de início o desamparo não pode ser superado senão pela aceitação de um protetor, torna-se imperioso o reconhecimento preciso do terreno onde um único passo em falso pode ser fatal. Mais depressa e decididamente do que Sérgio, Törless desenvolve um sentido para o ridículo de veleidades num meio que constrange a "prontidão permanente para disputas e lutas corporais" (p. 16). Integrar-se à vida do colégio interno significa, pois, submeter-se a leis implacáveis de um microcosmo em que - como formula um professor de Sérgio em conferência proferida no Ateneu - “a razão da maior força é a dialética geral". Curiosamente, porém, a primeira relação que Sérgio e Tórless estabelecem se dá ainda no limiar do jogo de forças que irão depois conhecer até a borra.

Logo no segundo capítulo de $O$ Ateneu, dedicado aos acontecimentos de seu primeiro dia no colégio, Sérgio narra o contato com Rebelo, o mais velho de todos, aspecto respeitável, olhos escondidos atrás de grossas lentes escuras, arguto e sisudo observador da ciranda dos internos. É Rebelo que acode Sérgio, em seu primeiro momento de fraqueza, "com um esforço de bondade sincero e comovedor", e o adverte em seguida da verdadeira realidade do colégio, em flagrante contraste com as palavras de moralismo grandiloqüente pronunciadas pouco antes pelo diretor. Mas o contato não vinga em amizade, e alguns meses depois Rebelo estará se afastando do Ateneu - "por causa dos olhos", acrescenta ambiguamente o narrador.

No colégio austro-húngaro, o primeiro relacionamento de Tórless acontece com uma personagem também situada fora dos padrões normais: trata-se do jovem príncipe H., rebento de exclusiva família aristocrática. Se para os outros internos esse príncipe logo se converte em objeto de escárnio e zombarias, em sua companhia Törless sente-se envolvido por uma espécie de atmosfera aurática, de extinto 
mundo feudal. Vivencia, assim, um período idílico, excêntrico posto que isento de toda brutalidade, que parece transcorrer como "numa capela situada fora do caminho". Mas é de curta duração, e a Törless não restará senão a intuição obscura de que "o bastão do racionalismo destruíra na hora errada algo delicado e fascinante". Pouco depois da ruptura com Törless, o príncipe retira-se do internato.

Chamando a $O$ Ateneu "romance pedagógico, ou de terror", Alfredo Bosi observa, em notável capacidade de síntese, que nele "cada momento narrado esconde um risco iminente ou recorrente" (16). Sendo assim, pode-se acrescentar que o batismo de Sérgio nessa dinâmica funesta acontece no episódio do quase afogamento nas águas sujas da natação. Entra em ação pela primeira vez, conforme reconstitui o narrador adulto, a perfídia do forte Sanches, que tenta enredar o recém-ingresso numa relação de favores e obrigações, semelhante àquela que, no romance austríaco, Reiting e Beineberg levarão às últimas conseqüências com Basini. Aqui, em consonância com a tendência narrativa já apontada de amplificar os acontecimentos na interioridade de Törless, o momento deflagrador das atribulações resulta da cena em que Reiting lhe comunica que descobrira o "ladrão de armários". É a notícia do delito que faz Törless sentir pela primeira vez, e de maneira obscura, a presença de um mundo desconhecido, noturno, que espreita por trás da fachada luminosa e organizada que parecia até então envolver a vida dos pais e de toda a "boa sociedade". Irrompe nesse momento a profunda crise que pouco antes já dera alguns sinais durante a visita, ao lado de Beineberg, à prostituta Bozena.

Rastrear a trajetória dos heróis pela arena dos colégios brasileiro e austríaco implica também proceder a um levantamento de particularidades relativas ao enredo. Salta aos olhos, primeiramente, a diversidade dos contatos e relações de Sérgio no Ateneu, o que de certo modo se prenuncia na ferina descrição dos companheiros de classe que se encontra no segundo capítulo (esta passagem de caracterização concentrada do coletivo é analisada por Alfredo Bosi sob o aspecto de "atento exercício de fenomenologia do olhar").

Rebelo, Sanches, Franco, Bento Alves, Egbert; em plano secundário, Malheiro, Barbalho, Ribas, Maurílio, Barreto, Rômulo e alguns outros... Extensa é a gama de indivíduos em cuja convivência irá cristalizar-se definitivamente a amarga aprendizagem de Sérgio. Sobre todos esses, porém, também sobre os professores e sobre todo o Ateneu, paira o vulto terrífico de Aristarco, na visão de Mário de Andrade "tipo heróico e sarcástico de diretor de colégio de uma unidade e um poder de convicção como não conheço outro congênere na literatura universal" (17).

Ao contrário de Pompéia, Musil não individualiza outros internos além dos poucos já mencionados. Refere-se eventualmente a certos nomes: Hofmeier, Moté, um polonês apelidado Dschjusch; mas também estes mal se distinguem da massa anônima que, na retrospectiva tardia de Musil (cf. nota 9), aparece como "algo a ser submetido". Descontando-se o breve relacionamento com o príncipe $\mathrm{H}$. e o envolvimento com Basini, Törless irá gravitar a maior parte do tempo em torno de Reiting e Beineberg, aliados eventuais, mas no fundo travando sempre encarniçada 
disputa pelo domínio irrestrito. Assim, se em $O$ jovem Törless as atribulações do ginasiano não precisam da diversidade dos contatos para se intensificarem, e as autoridades pedagógicas não caem sob o fogo cerrado do sarcasmo e da caricatura, Musil, em contrapartida, faz Reiting e Beineberg encarnarem uma vontade de poder que não tem paralelo em Sanches e em nenhum dos "vigılantes" do Ateneu, "tiranetes por delegação da suprema ditadura".

Valeria a pena observar mais de perto como se anunciam, no romance austríaco, os precursores dos "atuais ditadores". É primeiramente por meio de longa passagem em discurso indireto que o narrador apresenta traços centrais da personalidade de Reiting, que não conhecia prazer maior "do que atiçar pessoas umas contra as outras, submeter umas com ajuda das outras, alimentando-se dos agrados e das adulações forçados que extraía delas, por trás dos quais sentia a resistência do ódio de suas vítimas" (p. 52). Esse sadismo altamente refinado não constitui, entretanto, um fim em si mesmo, mas articula-se com muito cálculo em estratégia que concebe o internato como laboratório onde se devem exercitar habilidades que se farão necessárias no futuro - Reiting "sonhava com golpes de estado e altas políticas e em consequência queria tornar-se oficial. (...) Contudo, Reiting sabia impor-se. Por enquanto, é verdade, só em pequena escala. Era um tirano, e mostrava-se impiedoso com quem lhe resistisse" (p. 52-53).

A consideração de passagens posteriores do romance ajuda certamente a precisar melhor a observação retrospectiva registrada por Musil em seu diário. Apresentando a Tórless a tática empregada para enlaçar Basinı, as palavras de Reiting impõem forçosamente a lembrança de um político nacional-socialista que tinha como prática das ma1s básicas repetir uma mentira tantas vezes fosse necessário até sua transformação em "verdade": Joseph Goebbels. É através de obstinado sorriso irônico que o aprendiz Reiting submete sua vítima: "Tinha a impressão de que, sorrindo assim, seria capaz de transformá-lo num ladrão, ainda que até então ele não o fosse" (p. 58). E se o ministro para a Propaganda de Hitler foi sobretudo um exímio manipulador das massas, Reiting, numa das cenas finais do romance, arquitetando o linchamento de Basini pela classe, continua digno do paralelo histórico: "Se cada um de nós contribuir com um pouco, poderemos fazê-lo em pedacinhos. Aliás gosto desses movimentos de massa. Ninguém faz nada de especial, e ainda assim as ondas se erguem cada vez mais alto, até se abaterem sobre as cabeças de todos. Vocês vão ver, ninguém se moverá e ainda assim haverá uma tempestade gigantesca. Para mim será uma diversão extraordinária promover uma coisa dessas" (p. 157).

Já Beineberg marca sua oposição a Reiting expondo sempre que possível total desprezo pela política e por tudo o que se refere à mera "realidade exterior". Adepto de um misticismo irracionalista e hostil a qualquer idéia de humanismo, Beineberg não é, porém, menos eficiente em racionalizar a violência empregada contra os que são classificados como "mais fracos", pessoas que nada significam no "maravilhoso mecanismo do mundo" e cuja existência, por isso, não teria outro sentido senão servir ao aperfeiçoamento dos seres "superiores". Nas conversas que tem com Torless, recorre sempre a um mistifório de sacrifício e purificação para 
justificar as experimentações sádicas a que submete Basini: "Exatamente porque me custa torturar Basini - quero dizer, degradá-lo, rejeitá-lo -, exatamente por isso é bom. Pois exige sacrifício. Surtirá efeito purificador. Devo isso a mim mesmo; e preciso aprender com Basini, diariamente, que ser apenas humano nada significa, é mera aparência, uma macaquice..." (p. 80).

Regida, portanto, pela "lei do mais forte", a dinâmica do colégio, assim como propicia, por um lado, o surgimento eventual de déspotas implacáveis, não prescinde, por outro, da figura do bode expiatório. Franco, no Ateneu, e Basini, no internato em W., equivalem-se à medida que encarnam figuras sobre as quais a violência é exercida sem peias, em todas as variantes. Mas também essa equivalência guarda nuanças: Franco é, por assim dizer, o bode expiatório institucionalizado do estabelecimento, oprimido não só pelos outros internos, mas sobretudo por Aristarco, que sobre ele canaliza e descarrega tensões que de outro modo não se resolveriam senão através da desmoralização ou, o que seria muito pior para o diretor-empresário, prejuízos financeiros - exemplar nesse sentido é o episódio da "revolução da goiabada", em que o dilema vivido por Aristarco gera uma alusão paródica ao Hamlet. "Expulsar... expulsar... falir talvez" (p. 109). Franco, nas palavras do próprio narrador, funciona na economia do colégio como "bibelô do ensino intuitivo", papel a que só consegue subtrair-se pela morte voluntária.

O aspecto da opressão é reforçado ainda por outro traço comum à caracterização das personagens Franco e Basini: trata-se das referências, feitas por meio de cartas que chegam ao internato e são logo interceptadas, à difícil situação financeira das respectivas famílias. É, porém, plenamente conseqüente que Pompéia e Musil encaminhem essa questão também de forma diferenciada, enfatizando-a o primeiro em consonância com a mentalidade empresarial de Aristarco, e o segundo subordinando-a ao plano da sexualidade (18), que aliás, com maior ou menor intensidade, sempre ajuda a compor a constelação que caracteriza as "histórias de alunos".

\section{$A$ crise da puberdade}

Sendo o internato o espaço em que se processa a puberdade, o jogo de forças aí vigente tende, geralmente, a engendrar o homossexualismo - ou, dizendo de maneira mais apropriada, a submissão sexual do mais fraco ao mais forte. É o que se delineia logo nos primeiros momentos de Sérgio no Ateneu, submetido às investidas astutas do forte Sanches. Se, porém, quanto a esse primeiro embate o narrador deixa claro que se tratava tão-somente de esquivar-se das investidas do "pegajoso" colega, os relacionamentos posteriores de Sérgio com o robusto Bento Alves e o lânguido Egbert são pontilhados por ambigüidades que, como ilustra o episódio do violento rompimento com o primeiro, não se esclarecem inteiramente para o leitor. Como é sabido, isto valeu a Pompéia, no ensaio de Mário de Andrade, a acusação de ter desconhecido e sido incapaz, mesmo enquanto narrador, do sentimento puro da amizade. Mas não se estaria atribuindo aqui à personalidade atribulada do escritor componente que resulta forçosamente do ambiente representado, que levanta obstáculos de toda espécie ao cultivo da amizade? 
Também no Torless - tanto quanto no Doidinho ou no já citado Debaixo das rodas, e ainda em manifestações posteriores do gênero, como Los rios profundos, 1958, de Jose Maria Arguedas, na novela Katz und Maus (Gato e rato), 1961, de Gunter Grass, ou na narrativa autobiográfica Die Ursache (A causa), 1975, de Thomas Bernhard - o sentimento da amizade não existe de forma alguma ou só efemeramente consegue sobreviver no meio adverso. Em todos esses casos, a impossibilidade de até mesmo se vislumbrarem alternativas para suprir as carências emocionais leva ao adensamento da opacidade, conceito que ocupa posição central no estudo de Bosi sobre $O$ Ateneu (19). Por essa mesma via da impossibilidade, recrudescem as atribulações que, já sob condições normais, são próprias dessa fase de profundas transformações fisiológicas e psíquicas, na qual - recorrendo a uma formulação musıliana do romance $O$ homem sem qualidades - "uma campina de delicadeza, em que até então se brincara, é ceifada a fim de se extrair ração para um instinto determinado" (20).

Nas condições específicas do colégio interno, portanto, vemos exacerbaremse sobremaneira os conflitos da puberdade, e a esse respeito devemos a Araripe Jr., o primeiro crítico de $O$ Ateneu, observação das mais agudas: "Em tese - e é o que pretende provar o livro de Raul Pompéia -, o internato é o horror da seqüestração sexual; quero dizer: o internato tem como função geral fazer esquecer o sexo, provocando um desequilíbrio que nem ao menos encontra o sedativo da contemplação do elemento adverso, como nos estabelecimentos mistos" (21).

Mas se o crítico explicita aqui uma verdade básica da vida nos internatos, isto não implica em ausência total do elemento feminino. Pois o Ateneu é também o palco em que Ângela, a camareira de dona Ema, esposa de Aristarco, exercendo suas artes de sedução, "fendia-se em dois batentes de porta mágica e rodava em explosão o sabbat das lascívias" (p. 67). Sintomaticamente, é no contexto da confusa e precária sexualidade do adolescente, referindo-se à influência "dissolvente" de Ângela e aludindo de forma muito velada à masturbação, que Raul Pompéia emprega aquela que talvez seja a metáfora mais expressiva do romance: "O meio, filosofemos, é um ouriço invertido: em vez de explosão divergente dos dardos - uma convergência de pontas ao redor" (p. 61).

Torless vivencia igualmente o internato austríaco como meio dos mais espinhosos. Musil, no entanto, movido também aqui por seus princípios antinaturalistas, evita polemizar abertamente com as circunstâncias exteriores. Limita-se a referi-las de forma sucinta e contida, como nas passagens iniciais que falam da solidão do recém-ingresso ou anda numa passagem posterior, que ilustra exemplarmente a observação citada de Araripe Jr., já que o contexto em que se insere retrata a intensificação dos sofrimentos do adolescente, em virtude do impacto de sensualidade tão poderosa quanto desconhecida: "Eram as condıções específicas do instituto que produziam isso. Num lugar em que as forças jovens e impetuosas ficavam aprisionadas atrás de muros cinzentos, elas represavam a fantasia formada por imagens voluptuosas, inteiramente arbitrárias, que punham mais de um interno fora de si" (p. $155)$. 
No mundo de Törless, tanto quanto no Ateneu, o "horror da seqüestração sexual", o aprisionamento das "forças jovens e impetuosas", não exclui - antes suscita - a presença de figura feminina reduzida a uma sexualidade puramente carnal. Trata-se da prostituta Bozena, que desperta em Törless pela primeira vez, no início de sua estadia no internato, a intuição de afinidades obscuras entre as formas de vida burguesa que conhecia de casa e uma outra realidade de fantasias e transgressões sexuais. Também aqui, portanto, faz-se ouvir o convite irresistível ao "sabbat das lascívias", com a promessa de dissolução, de aniquilamento da personalidade atribulada numa sensualidade animalesca. Por mais fortes - até mesmo patéticas que sejam expressões pompeianas como "apetite de cupim pela demolição invisível do que está constituído", "vivescência vermicular dos estímulos torpes", "propaganda obscura da lama", elas não estariam deslocadas na caracterização da fase do desenvolvimento de Törless marcada pelo impulso violento, desesperado, de autohumilhação: "Bozena aparecia-lhe como uma criatura de inacreditável baixeza, e sua relação com ela, a sensação que era obrigado a suportar, parecia-lhe um cruel culto de auto-sacrificio. Excitava-o ter de abandonar tudo aquilo em que normalmente estava encerrado, sua posição privilegiada, as idéias e os sentimentos que lhe foram incutidos, tudo aquilo que nada lhe dava e o oprimia. Excitava-o fugir em desabalada carreira rumo àquela mulher, nu, despojado de tudo" (p. 38-39).

$E$ bem verdade que, na representação da vivência erótico-afetiva do adolescente, Raul Pompéia e Robert Musil não deixam faltar o pólo oposto àquele em que se situam Ângela e Bozena. Acontece, porém, que o encontro com o lado sublime do feminino leva significativamente para fora do espaço e da dinâmica do internato, no final da trajetória do herói. Na primeira parte do $12^{\circ}$ e último capítulo de OAteneu, Sérgio narra sua convalescença sob os cuidados de dona Ema, período da mais límpida felicidade, envolto em atmosfera musical e marcado por uma percepção virginal, próxima à experiência da revelaf̧ão, do mundo e da natureza: “Tudo me parecia desconhecido, renovado. Curioso resplendor revestia aquele espetáculo. Era a primeira vez que me encantavam assim aquelas gradações de verde. (...) Tetos de casas, que novidade! que novidade o perfil de uma chaminé riscando o espaço! Ema entregava-se, como eu, ao prazer dos olhos" (p. 142). A relação da subjetividade com a realidade exterior é balizada agora, como se vê, pela transparência (22), o que gera passagens de lirismo o mais delicado e etéreo, momentos de exceção nessa crônica de sofrimentos.

Mas como resolver as ambivalências do relacionamento com uma mulher que até no anagrama do nome parece representar a imago da mãe? Pompéia simplesmente as potencializa: " $E$ fora preciso que soubesse ferir o coração e escrever com a própria vida uma página de sangue para fazer a história dos dias que vieram, os últimos dias..." (p. 146).

Já no romance austríaco, podando nesse aspecto a possibilidade de sublimação, é a presença amorosa da própria Frau Törless que vem selar a superação dos conflitos e atribulações do filho. Ao lado da mãe, na cena final, passando a caminho da estação de trem pela casa de Bozena em meio a um pequeno bosque, este lugar 
vivenciado outrora como demoníaco surge a Törless em dimensões insignificantes: "E aspirou o odor levemente perfumado que se evolava do regaço de sua mãe".

Como em relação à tese da "seqüestração sexual", também quanto à libertação, por mão feminina, das agruras e angústias da vida no internato, a ponte entre os romances de Pompéia e Musil pode ser completada por outra arguta constatação de Araripe Jr.: “A conclusão única a tirar de tudo isto é que os ateneus podem ser fatais aos meninos que, ainda aos dezesseis anos, não prescindem de socorro das mães e que arriscam-se a morrer inanidos se não encontram mulher para aquecê-los no regaço" (23).

\section{A pedagogia do autoritarismo}

Em $O$ Ateneu, porém, não é o momento da pacificação dos conflitos sob o influxo amoroso do feminino, portanto também o momento da superação fecunda das atribulações de internato, que fica com a última palavra, mas sim o episódio do incêndio em que o narrador, como que partilhando da voluptuosidade das chamas, parece regozijar-se. Vingança “desnecessária” do eterno ressentido Raul Pompéia, como queria Mário de Andrade? Ou aqui não assistiria razão antes a Alfredo Bosi, que reconhece no sinistro final um desdobramento conseqüente do idílio de Sérgio com dona Ema (24)?

Seja como for, o caminho para uma compreensão adequada da destruição do colégio não deve passar ao largo daquilo que constitui propriamente a especificidade das "histórias de alunos", destacando-as das muitas obras protagonizadas por crianças ou adolescentes (entre as quais se sobressaem os romances clássicos de Charles Dickens) e também distinguindo-as do "romance de formação", gênero em que $O$ Ateneu é às vezes incluído de forma acrítica (25). Esse traço distintivo diz respeito ao confronto crescente entre instituto educacional e educando, mais precisamente entre as formas institucionalizadas, via de regra autoritárias, de transmissão do saber, e a sensibilidade e a consciência crítica emergentes.

Quanto a este ponto, a perspectiva comparativa revela que em poucas histórias do gênero encontraremos embate tão intenso, trágico até, como o que se trava entre Sérgio e o Ateneu do doutor Aristarco Argolo de Ramos, "autocrata excelso dos silabários". E isso a despeito de se poder sustentar que a crise que acomete Törless no internato austríaco possui uma magnitude superior à narrada por Pompéia em seu romance. Como já apontado anteriormente, na obra de Musil o choque do indivíduo com a estrutura coercitiva da instituição sofre espécie de refração para a interioridade, prismatizando-se em indagações existenciais. A relação de Törless com a matemática - e o respectivo professor - ilustra exemplarmente essa tendência: quando todo o meio circundante começa a vacilar e revestir-se de um aspecto fantasmagórico, o pupilo irá procurar apoio naquela que se apresenta como a mais segura das ciências, na tentativa de proceder a uma busca rigorosa, cartesiana, do próprio eu. Inesperadamente, porém, a reflexão sobre conceitos matemáticos - as noções de núméros imaginários e irracionais, assim como de infinito - converte-se 
em nova fonte de vertigens. Sobrevem então o momento (mesmo com a ênfase narrativa deslocada para a interioridade) em que a consciência crítica do aluno irá colidir frontalmente com a rígida pedagogia vigente, como o demonstram as palavras do professor de matemática a quem Törless recorre em busca de ajuda: "Você deve se contentar em pensar que tais conceitos matemáticos são apenas puras necessidades inerentes ao pensamento matemático. (...) caro amigo, você simplesmente precisa acreditar, quando um dia souber dez vezes mais matemática do que hoje, compreenderá; por enquanto precisa acreditar!" (p. 104).

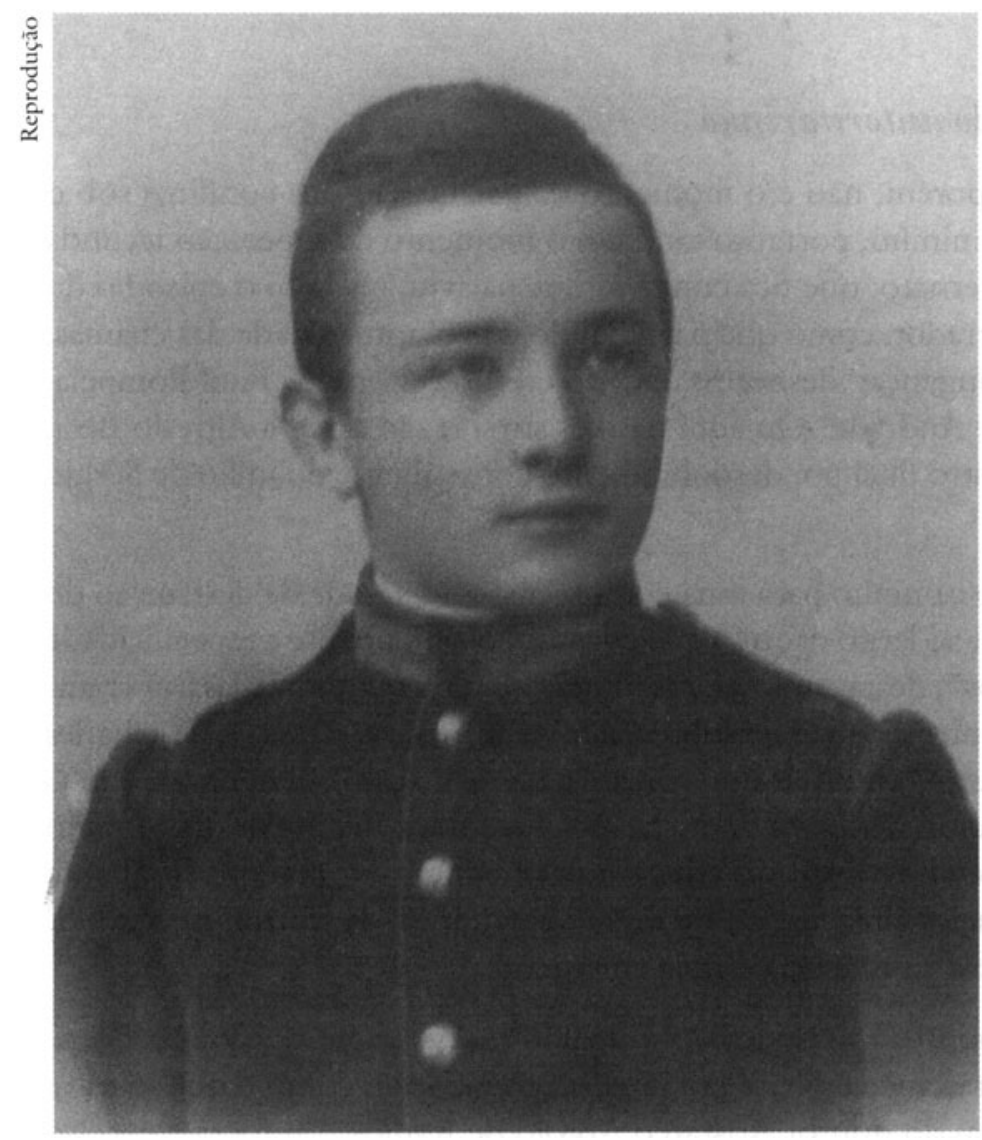

Robert Musil em 1894, aos 14 anos, como aluno interno em Mahrisch-Wersskirchen

Evidenciada a incapacidade do reputado professor em estabelecer um diálogo vivo com o aluno inquieto, o próximo passo de Törless, após breve e frustrada tentativa com um volume de Kant, será desenvolver a auto-reflexão num diário intitulado de forma tão ambiciosa quanto patética De natura hominum. Já as primeiras palavras registradas dão pleno testemunho da magnitude de suas atribulações: "Devo estar doente... insano! Insano - o que mais me faz estranhar assim coisas que são normais para os outros? E por que essa estranheza me atormenta? E por que essa estranheza provoca em mim a sensualidade carnal? (...) O mundo para mim está cheio de vozes mudas: serei um visionário ou um alucinado?” (p. 120-121). 
Passagens como estas revelam a razão de, no título escolhido por Musil, as atribulações se sobreporem à menção do colégio. E por mais abissais que essas tenham sido, no fundo o romance conta uma história de vigorosa afirmação individual, o que também facilita ao jovem Musil a disposição de não ultrapassar um discreto desmascaramento das relações vigentes na instituição educacional. Assim, o desfecho da história de Törless é marcado por imagens de reconciliação (a cena final com a mãe) e fecundidade: impõe-se ao jovem a visão de um "jardineiro regando seus canteiros todas as manhãs, com uma constante, paciente bondade" (p. 176); depois a conversão positiva da imagem inicial, já citada, da pequena árvore castigada pelo inverno: "Uma fase se encerrara, a alma formara mais um anel, como na casca de uma árvore jovem. Essa sensação poderosa, para a qual não havia palavras, desculpava tudo o que acontecera" (p. 181).

N'O Ateneu, ao contrário, suspendendo a crônica dos embates do menino Sérgio com a instituição onipotente, imagens de combustão, de chamas devastadoras e, por fim, a entoação lúgubre do "funeral para sempre das horas". "Fim brusco de mau romance", como formula a amarga auto-ironia do narrador? Ou esse final apocalíptico não se justifica numa obra em que a elevada elaboração artística enforma um mundo ouriçado de pontas insofismáveis, cuja atmosfera se torna definitivamente irrespirável após a efêmera vivência da possibilidade amorosa? Na plasmação desse "ouriço invertido" em que ao sujeito não resta senão esfolar-se, sobreleva a caracterização de Aristarco, pródiga de momentos em que a verve satírica e caricatural produz páginas que encontram poucos paralelos em nossa literatura. As aparições do "grande diretor" são sucessivos rompantes de megalomania e retórica, como que condenado a corresponder sempre à fórmula peremptória do "mestrículo" Venâncio, seu adulador de plantão: “Acima de Aristarco - Deus! Deus tão somente; abaixo de Deus - Aristarco".

Ainda que a influência perniciosa de uma tal figura sobre os educandos dispense quaisquer comentários suplementares, valeria lembrar nesse contexto uma breve passagem do Emílio em que Rousseau desaconselha para seu pupilo a leitura de certo historiador: “Mas ele é político, é retórico, é tudo o que não convém à idade do jovem" (26).

Mas a retórica aristarquiana, além de revestir um caráter megalômano e autoritário, cumpre função marcadamente ideológica, na medida em que confere aparência de abnegação e sacrifício às manobras de um mestre consumado do marketing. Como a perspectiva post eventum se impõe já na abertura do romance, desmascaramento converte-se na principal palavra de ordem do projeto narrativo a que se lança o Sérgio adulto, e isto logo à primeira menção do colégio: "Ateneu era o grande colégio da época. Afamado por um sistema de nutrido reclame, mantido por um diretor que de tempos a tempos reformava o estabelecimento, pintando-o jeitosamente de novidade, como os negociantes que liquıdam para recomeçar com artigos de última remessa; o Ateneu desde muito tinha consolidado crédito na preferência dos pais, sem levar em conta a simpatia da meninada, a cercar de aclamações o bombo vistoso dos anúncios" (p. 12). 
Ensino como mercadoria e veículo de prestígio social em correspondência velada com o rosto empresarial e especulador de Aristarco; ensino como missão nobre e abnegada em correspondência ostensiva com a máscara de educador e "levita": desta contradição de base, que perverte qualquer possibilidade de uma aprendizagem verdadeira e contamina todos os demais aspectos da vida no colégio, o narrador extrai os mais variados efeitos, num esforço febril de desmascaramento que culmina no episódio do descerramento do busto brônzeo do diretor. A “obsessão da própria estátua", cujo diagnóstico aparece logo no primeiro capítulo, está prestes a apaziguar-se. Mas junto com a ovação, os louros e o bronze, vem a caricatura mais genial, que com requintes de sutileza desvenda ao leitor a alternância de nada menos do que sete estados de espírito do homenageado (27).

Articulados, todavia, na esfera psicológica, esses sucessivos desmascaramentos são uma arma tardia do Sérgio adulto. A dimensão do tempo narrado - isto é, das vivências do menino - é marcada pela desorientação nessa espécie de "labirinto de Creta", como formula Araripe Jr. (28), pela impossibilidade de afirmação pessoal em face da violência institucionalizada. $O$ impasse daí resultante só se resolverá pelo recurso ao incêndio, espécie de Deus ex machina que faz aluir o mundo de Aristarco e o rebaixa - de Deus Padre em pessoa (p. 19), de Júpiter tonitruante (p. 50) - à condição de "um deus caipora, triste, sobre o desastre universal de sua obra".

Se num primeiro plano esse ato de terrorismo narrativo parece perpetrado exclusivamente contra a figura do diretor, de uma perspectiva crítica mais ampla, atenta sobretudo a considerações da psicologia sobre as explosões irracionais com que o indivíduo reage à pressão social, torna-se possível interpretá-lo também em função de outra significativa peculiaridade do romance $O$ Ateneu. Trata-se da concepção de internato - e, por extensão, de sociedade - que Raul Pompéia explicita através do doutor Cláudio, o único professor contemplado com certa simpatia, embora restrita ao aspecto intelectual. Abre-se amplo espaço no romance à reprodução de quatro conferências que este profere no âmbito das atividades do "Grêmio Literário Amor ao Saber": sobre a literatura e a vida nacional; sobre arte conferência vasta e densa, que se configura como esboço histórico, filosófico e antropológico das várias manifestações artísticas; depois o bloco de considerações cosmogônicas, sobre o início explosivo do universo; e por fim, contraponto teórico ao assunto do romance, a conferência sobre educação.

O início desta é desconcertante; por meio de perguntas, o conferencista procede a um levantamento das mazelas que o próprio Sérgio já experimentara no Ateneu: “É uma organização imperfeita, aprendizagem de corrupção, ocasião de contato com indivíduos de toda origem? O mestre é a tirania, a injustiça, o terror? O merecimento não tem cotação, cobrejam as linhas sinuosas da indignidade, aprova-se a espionagem, a adulação, a humilhação, campeia a intrıga, a maledicência, a calúnia, oprimem os prediletos do favoritismo, oprimem os maiores, os mais fortes, abundam as seduções perversas, triunfam as audácias dos nulos? A reclusão exacerba as tendências ingênitas?". Se a resposta do conferencista fosse irônica ou cínica, 
veríamos delinear-se aqui - e não sem intenção crítica - o topos do mundo às avessas. Mas a conclusão é profundamente séria: "Tanto melhor: é a escola da sociedade".

Em que pese a perspectiva insólita, mesmo trágica, desse porta-voz de Pompéia, as considerações pedagógicas aqui expostas não se destacam propriamente pela originalidade, pois a apologia de um ensino voltado em primeiro lugar para a vida prática tem profundas raízes na tradição ocidental: Non scholae, sed vitae discimus (29). Também que a escola, em acepção mais moderna, seja uma antecipação concentrada das relações sociais, espécie portantó de Estado miniaturizado, esta é uma concepção que se exprime em várias histórias do gênero. Em uma passagem referente à aversão de Törless pela disputa encarniçada entre Reiting e Beineberg, Musil a formula de forma ainda mais particularizada: "Contudo, estava encerrado dentro daquele universo, e constatava diariamente o que significava desempenhar o papel principal num Estado - numa instituição assim cada sala de aula é um pequeno Estado em si" (p. 53).

Mas enquanto o processo formativo de Törless, o aprimoramento de suas potencialidades artísticas, exige sua saída do internato em que subterraneamente vigoram relações de barbárie, no romance de Pompéia a adaptação do menino às condições ingratas do meio impõe-se como preparação inexorável para a existência adulta. Primeiro na escola, depois na sociedade, o indivíduo é confrontado com a exigência de afirmar-se num meio em que, como se diz na conferência sobre educação, "os deserdados abatem-se" ou - na formulação já citada - "a razão da maior força é a dialética geral". Hipostasiar o termo dialética significa precisamente revelar sua total ausência no mundo de $O$ Ateneu. Pois limitada à função de mero reflexo ("não é o internato que faz a sociedade; o internato a reflete"), a escola encontra-se degradada à condição de reprodutora da ideologia dominante, impossibilitada de propiciar o conhecimento autêntico e, sobretudo, de apoiar o educando no difícil caminho da auto-reflexão crítica e da autonomia. Em vez disso, em $O$ Ateneu nada é contrariado mais frontalmente do que essa tarefa que, conforme observação de Adorno, deveria ser a primeira de todas para a educação (30).

A racionalização da violência, tal como se infere das palavras do doutor Cláudio, estaria assim justificando não apenas o jogo de forças vigente no Ateneu (sob a égide da "suprema ditadura" aristarquiana), mas também, indiretamente, as práticas com que, no internato austríaco, um Reiting exercita sua aspiração de poder "por enquanto, é verdade, só em pequena escala".

Voltando o olhar ao próprio passado para embasar as narrativas sobre as atribulações e os sofrimentos dos meninos Sérgio e Törless no confronto com o meio escolar adverso, Raul Pompéia e Robert Musil incorporaram às suas ficções, cada um a seu modo, traços de comportamento e mentalidade que se objetivariam algumas décadas mais tarde em realidade histórica. Musil pôde viver o suficiente para reconhecer o futuro favorável que aguardava seus pequenos tiranos Reiting $\mathrm{e}$ 
Beineberg, assim como as experimentações desumanas executadas na "câmara vermelha" do internato. Mas também quanto a Pompéia, a retrospectiva histórica permite avaliar com suficiente clareza - e isto a despeito de suas posições republicanas e antiescravocratas - as conseqüências últimas de concepções implícita e explicitamente presentes em seu romance: ou seria ir longe demais afirmar que o darwinismo social apresentado pelo eu-narrador como determinante da realidade do colégio (e elevado ainda a princípio universal), pode in extremis instrumentalizar-se como justificativa dos campos de extermínio do século XX?

Aparentemente meras narrativas sobre as vicissitudes próprias da "adolescência colegial" (Mário de Andrade), no fundo as obras centradas nesse eixo temático extrapolam os limites de um drama mais ou menos pessoal e configuram, em elevado grau, a possibilidade antecipatória da arte. Fica claro, no entanto, que o conceito de "antecipação" aparece aqui dotado de sinal negativo, apontando assim em sentido oposto ao vislumbrado por Ernst Bloch no "ainda não" do pensamento utópico, ou por Adorno na "corrente subterrânea coletiva" inerente a toda grande formação lírica. Pois as ficções de Pompéia e Musil esboçam mundos em que se projeta a precariedade de autonomia individual em face de estruturas cada vez mais coercitivas, registram o crescente estranhamento que envolve as relações da subjetividade com a realidade exterior (que se pense apenas nas palavras com que Törless abre $o$ seu diário).

Contudo, por meio da sublimação, primeiro na relação amorosa, em seguida na destruição do mundo odiado, e do retorno prosaico, embora lúcido e amadurecido, à família, Pompéia e Musil criam brechas que ainda resguardam o indivíduo do aniquilamento no confronto desigual com o meio onde imperam relações de barbárie. Mas quando esta transpôs a realidade intramuros da escola e se instalou em todas as esferas da vida social, quando a opacidade se tornou absoluta, então dificilmente o herói colegial poderá descortinar "meato de passagem" entre as puas do meio.

O desdobramento histórico de tendências apreendidas em estado latente nas duas narrativas aqui consideradas possibilitaria à perspectiva crítica transpor algumas décadas e abrir-se à novela Gato e rato, do escritor alemão Günter Grass (1927) (31). E que nesta pequena obra-prima a relação obcecada do adolescente Joachim Mahlke com o ginásio Conradinum se constitui como ponto de fuga de uma representação radicalmente crítica da sociedade nacional-socialista, a qual, tocando em pontos nevrálgicos da sociedade alemã do pós-guerra, valeu ao escritor acusações, inclusive por via judicial, de blasfềmia, obscenidade e calúnia das instituições (32).

Com admirável mestria narrativa, Grass faz com que diversos componentes de uma intrincada constelação pessoal convirjam para a ambição de, condecorado com a Cruz de Ferro, proferir uma conferência no salão nobre da escola de onde fora expulso: "Nosso ginásio, aquele caixote embolorado e impossível de ventilar, e particularmente o salão nobre, significavam muito para Joachim Mahlke, e te obrigariam, mais adiante, a realizar esforços supremos" (p. 35) (33). 
Que a renúncia a considerações mais detalhadas sobre Gato e rato permita ao menos uma breve referência à personagem de Waldemar Klohse, professor de matemática e ao mesmo tempo o diretor da instituição educacional por cujo reconhecimento Mahlke trava a inglória luta metaforizada no título da novela. Pois se Mário de Andrade não encontrava na literatura universal diretor de colégio congênere à figura de Aristarco, pode-se dizer que com algumas pinceladas precisas, Grass confere à sua personagem "uma unidade e um poder de conviç̧ão", nas palavras do crítico brasileiro, capazes efetivamente de colocá-la ao lado da genial criação de Pompéia.

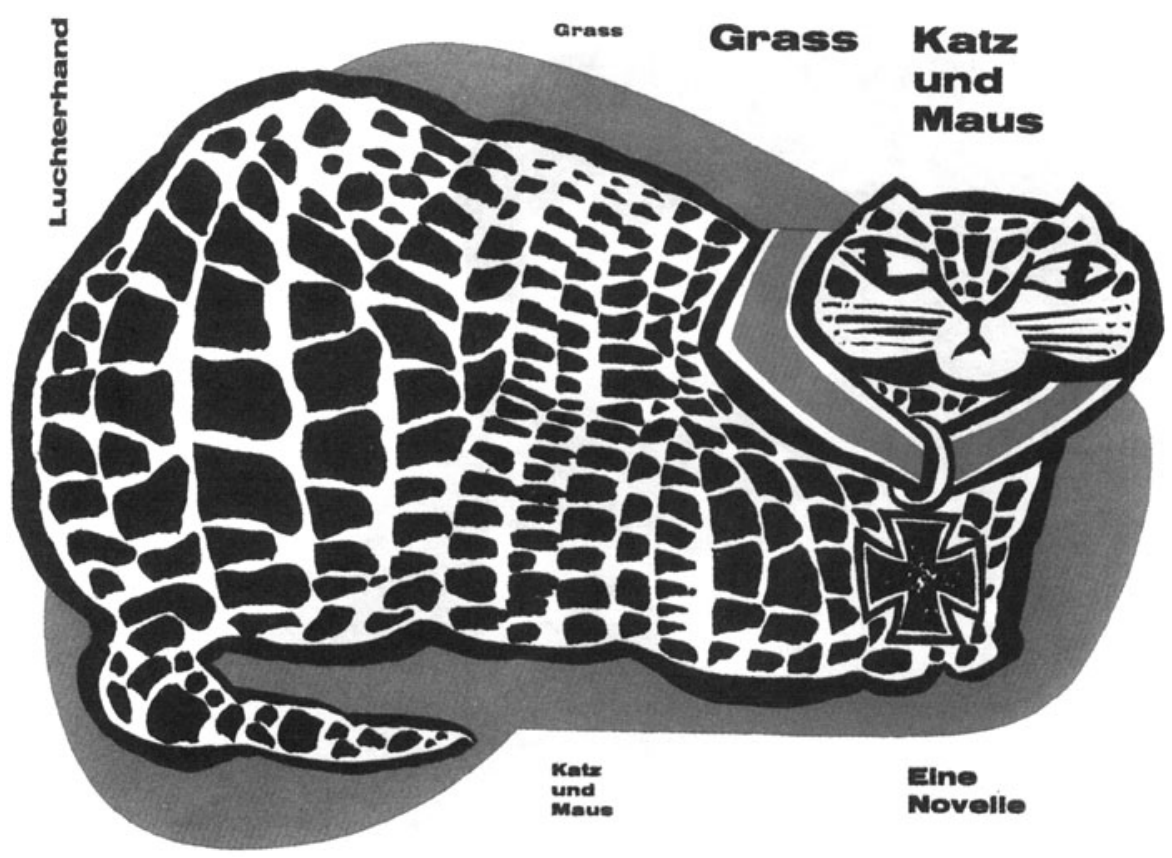

Ilustração feita por Grass para sua novela Gato e rato, publicada na Alemanba em 1961

Encarnação consumada do caráter autoritário, também Klohse enxerga no colégio em que exercita sua megalomania o "umbigo do mundo", e parece igualmente padecer da obsessão da própria estátua. Mas como o contexto histórico é outro, as técnicas de "nutrido reclame" cederam lugar às de propaganda ideológica explícita. Com a voz altissonante, o seu característico "hálito de hortelã que representava o odor de ciência pura", Klohse revela-se exímio manipulador da mentalidade adolescente: nas alocuções que antecedem os discursos proferidos por alunos e ex-alunos portadores da Cruz de Ferro, exalta com palavras de Schiller e outros clássicos as virtudes militares apregoadas pelo estado hitlerista e arvora-se, ele próprio, à condição de herói nacional. Sob a aparência de inflexível dignidade, pune eventuais deslizes por parte dos alunos e por fim, argumentando com o regulamento inviolável da instituição, destrói de uma vez por todas - e isto sem renunciar a requintes de crueldade - o objetivo de vida de Mahlke. 
Com seu desfecho trágico, a novela de Grass sobre a trajetória do aluno Joachim Mahlke insere-se de forma conseqüente numa tradição literária cujo núcleo fundamental reside na experiência que talvez se possa sintetizar no termo heteronomia. Pois as várias "histórias de internos ou alunos" - estejam elas contextualizadas na Alemanha nacional-socialista, no Império austro-húngaro em sua fase de dissolução ou nos anos finais do Segundo Reinado brasileiro - narram todas o recrudescimento de uma vivência que efetivamente se inicia enquanto "protótipo da alienação social".

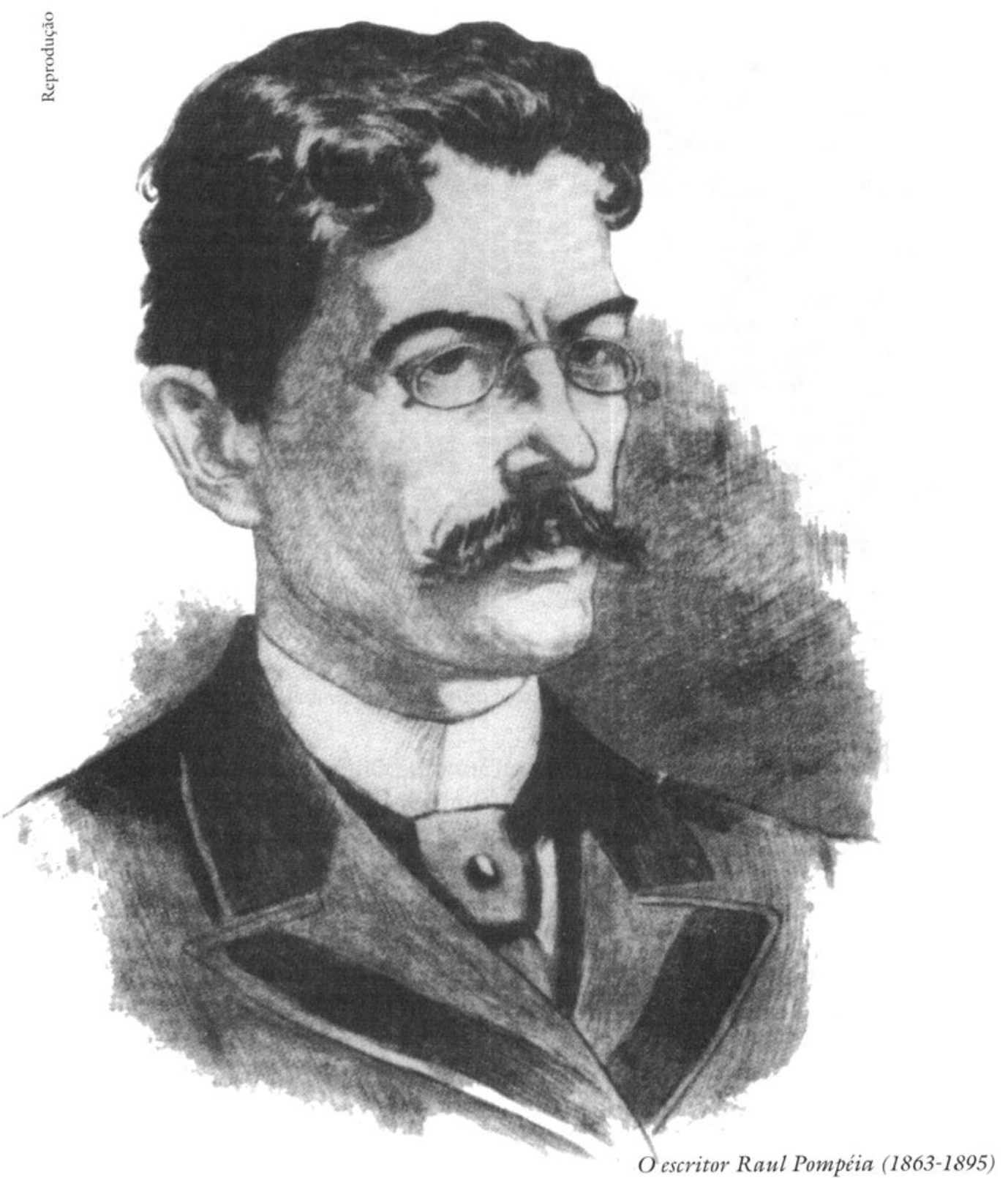


A consideração dessas obras em chave comparativa e diferencial, longe de nivelar suas respectivas peculiaridades, permite discuti-las numa dimensão amplia$\mathrm{da}$, de uma perspectiva matizada pelo contraste mas também sempre atenta à base temática sobre a qual se assentam os traços constitutivos desse tipo narrativo fortemente representado na literatura ocidental. Graças ao reconhecimento dessa base temática comum, a possibilidade de estabelecer vínculos também entre obras separadas por larga distância temporal, e mesmo inseridas em contextos culturais distintos, se sobrepõe ao mero levantamento analítico das diferenças, desde as estilísticas até as ideológicas, que de outra forma - isto é, ausente o esforço de abstração e síntese - logo esgotaria a perspectiva comparativa.

Avançando um pouco mais na direção dos nexos possíveis, talvez caiba perguntar aqui se a aproximação dos diretores Aristarco Argolo de Ramos e Waldemar Klohse não possibilitaria até mesmo o estabelecimento de uma ponte entre "o bombo vistoso dos anúncios", a propaganda desmascarada obsessivamente como a alma do negócio Ateneu, e a propaganda que, na novela de Grass, alicerça um sistema social sob vários aspectos já prefigurado, em escala devidamente miniaturizada, nas ficções de Pompéia e Musil (34). Para essa especulação não seria irrelevante a mediação de uma personagem como Reiting, em que vimos delinear-se, seguindo sugestão do próprio Musil, um precursor do ministro da Propaganda Joseph Goebbels.

A fundamentação de tal hipótese pressupõe, porém, um aprofundamento em estudos sociológicos, o que talvez se revele excessivo no âmbito de uma abordagem comparativa de textos ficcionais. Da mesma maneira, remontando às referências rápidas, em páginas anteriores, a textos de Adorno sobre educação, não fica difícil imaginar semelhante deslocamento do enfoque para o terreno da pedagogia. ( $E$ para a discussão contrastiva do sistema educacional esboçado nas narrativas aqui consideradas, quantas sugestões não se colheriam na obra de um Paulo Freire!)

Contudo, ainda que o desdobramento eventual dessas propostas críticas possa afastar-se em demasia do ensejo primeiro da interpretação literária, que são os próprios textos, é plenamente legítimo e compreensível que elas sejam suscitadas pelo tema enfocado neste trabalho. Pois centradas na experiência primordial da heteronomia, mas também levantando desde já a aspiração inalienável por uma condição autônoma e emancipada, essas pequenas obras-primas que tematizam o embate da criança ou do adolescente com o meio adverso da escola vão literalmente à raiz das grandes questões do indivíduo e da sociedade.

\section{Referências bibliográficas}

10 Ateneu. In: Aspectos da literatura brasileira. $6^{\mathrm{a}}$ ed. São Paulo, Martins Fontes, 1978, p. 173-184, cit. p. 180.

2 Lautréamont e Raul Pompéia. In: O Atenen - Retórica e paixão (direção e organização Leyla Perrone-Moisés). São Paulo, Brasiliense/Edusp, 1988, p. 15-40. No final do ensaio - antes porém da referência à "função específica da literatura como traba- 
lho de linguagem" - levanta-se a hipótese, um tanto frágil, de um certo distanciamento em relação a valores então vigentes na Europa estar na base do posicionamento violentamente anti-retórico comum tanto ao uruguaio-francês Lautréamont (Isadore Ducasse) como ao brasileiro Pompéia.

Também Álvaro Lins encontra para Pompéia um referencial comparativo na cultura francesa: no breve texto "Dois adolescentes: Cocteau e Pompéia" esboça uma aproximação das obras $O$ Ateneu e Les enfants terribles e, por extensão, das personalidades "adolescentes" de seus autores. In: Orelógio e o quadrante. Rio de Janeiro, 1964, p. 131-139.

3 Lembrando, primeiramente, dois grandes romances. Nos Buddenbrooks (1901), o jovem Thomas Mann faz com que a decadência da família hanseática se consume com o destino do menino Hanno, cuja sensibilidade artística não resiste à "prova de fogo" da escola: enfraquecida a vontade de viver, Hanno, após derradeiras humilhações em sala de aula, deixa-se levar pelo tifo. E cinco anos depois, ficando na mesma família, o "acerto de contas" de Heinrich Mann com seu período escolar em Lübeck: Professor Unrat ou O fim de um tirano (filmado em 1930 como $O$ anjo azul). Remontando ao ano de 1891, pode-se mencionar nesse contexto Früblings Erwachen. Eine Kindertragödie in drei Akten ( $O$ despertar da primavera. Uma tragédia infantil em trếs atos), de Frank Wedekind.

4 R. Minder: Kadettenhaus, Gruppendynamik und Stilwandel von Wildenbruch bis Rilke und Musil. In: Kultur und Literatur in Deutschland und Frankreich. Frankfurt a. M., 1977.

5 Do romance de Hermann Hesse há tradução brasileira de Álvaro Cabral: Debaixo das rodas. Rio de Janeiro, Civilização Brasileira, 1971 (há, ainda, outra edição da mesma tradução com o título livre Menino prodígio, Rio de Janeiro, Record, s.d.). A tendência acima constatada reflete-se no início do quarto capítulo - como que preludiando o fim trágico do herói Hans Giebenrath, Hesse refere-se aos casos de suicídios (menos freqüentes, porém, do que os de fugas) registrados em instituições como o seminário protestante de Maulbronn: “Ocasionalmente (...) havia algum desesperado que encontrava rápida e sinistra solução para os seus dramas juvenis lançando-se de uma janela para o claustro ou para o rio, quando não com um tiro no meio do peito".

6 Escrito em 1903 e publicado em 1906, o romance As atribulaçōes do pupilo Törless, como poderia ser intitulado em português, foi traduzido em 1981 por Lya Luft sob o título $O$ jovem Törless (Nova Fronteira). A segunda edição, acrescida do ensaio "Törless ignotus", de Karl Corino, e de material iconográfico, é de 1996; o texto de Musil será citado aqui de acordo com esta edição, procedendo-se porém, em alguns trechos, a pequenas alterações.

7 Em carta de 9 de dezembro de 1920, dirigida a um ex-professor de alemão que se recomendava sentimentalmente à lembrança do "grande poeta", Rilke caracteriza as experiências de interno em termos como: "uma provação descomunal", "um abismo de carências imerecidas", "sofrimento intrincado", "uma única maldição terrível". Os horrores suportados pela criança são comparados em determinado momento com os descritos por Dostoiévski nas Recordações da casa dos mortos. In: Briefe, Zweiter Band: 1914 bis 1926. Insel Verlag, 1950, p. 200-206. 
8 Ver nota 95 do "Diário" (caderno 33, que vai do verão de 1937 ao final de 1941 ). Nesta mesma nota em que relembra o sistema de "adestramento" a que eram submetidos os alunos, Musil se pergunta se a sua obsessão por limpeza não seria uma espécie de supercompensação das vivências de internato. E ao final da nota: "Por que meus pais não protestaram? Ainda hoje incompreensível. Deus!". In: Tagebücher, Aphorismen; Essays und Reden. Hamburg, Rowohlt Verlag, 1955, cit. p. 463.

9 Ver nota correspondente ( $\mathrm{n}^{\circ}$ 10): "Reiting, Beineberg: os ditadores atuais in nucleo. Também a concepção de massa como algo a ser submetido" (Id., ibid., p. 441).

10 Em sua monografia Robert Musil (Rowohlt, Hamburg, 1963) Wilfried Berghahn faz, no capítulo dedicado ao Törless (p. 33), a seguinte observação: "O olhar de Musil, nessa obra escrita em 1903, vai até o fundo da decência ilusória, da crença otimista de que as pulsões estavam domesticadas e que só em tempos imemoriais a embriaguez de sangue teve uma chance de subjugar a razão, e descobre quão iminente está a próxima irrupção. O Törless talvez seja o livro mais premonitório escrito antes da Primeira Guerra Mundial”.

11 Também na literatura brasileira o tema da escola, evidentemente, não está restrito à forma romanesca. Em "Conto de escola", de Machado de Assis, o eu-narrador apresenta uma experiência escolar como momento fundamental de sua formação. Em largos trechos dos volumes Balão cativo e Chão de ferro - para citar exemplo mais recente - o memorialismo de Pedro Nava estabelece, conforme observou Davi Arrigucci Jr., uma "relação oblíqua" com o romance de Pompéia (cf. "Móbile da memória". In: Enigma e comentário. São Paulo, 1987, p. 67-111).

12 Vale lembrar aqui a presença do tema da escola também na obra de vida de Musil. No quinto capítulo do primeiro volume do romance, reconstituindo a história da "formação" de Ulrich, o narrador fala dos inconvenientes acarretados por uma redação do ginasiano sobre o amor à pátria. A relativização do patriotismo em geral, estendida em seguida ao plano teológico - "provavelmente Deus também prefira falar do seu mundo no Conjunctipus potencialis ( hic dixerit quispiam = aqui se poderia objetar)" -, vale ao jovem especulativo, já tateando pelo "sentido de possibilidade", a transferência de exclusiva instituição educacional vienense, "que fornecia os mais nobres alicerces do estado", para um inexpressivo internato belga.

13 O Ateneu, opacidade e destruição. In: Céu, inferno. São Paulo, 1988, p. 33-57.

14 Cf. o ensaio "Tabus acerca do magistério". In: Educação e emancipação (tradução de Wolfgang Leo Maar). São Paulo, 1995, p. 97-117, cit. p. 112.

15 O Ateneu. 14ª ed. São Paulo, Ática, 1991, p. 60. As indicações de página seguintes referem-se a essa edição.

16 Alfredo Bosi, op. cit., p. 37.

17 Mário de Andrade, op. cit., p. 180.

18 Cabe recordar aqui que Basini é degradado efetivamente a objeto das experimentações sádico-sexuais de Reiting e Beineberg a partir da descoberta de que roubara dinheiro do segundo para saldar uma dívida junto a Reiting, cujas chantagens se tornavam cada vez mais implacáveis. 
19 O termo mencionado manifesta-se já no expressivo título "Opacidade e destruição". A meu ver, o intérprete tocou assim num ponto nodal das várias histórias do gênero. As atribulaçōes do pupilo Törless referem-se por vezes, de forma explícita, a um mundo "opaco", em que as palavras ricocheteam (p. 32; p. 73) e os olhares executam "um trajeto cada vez mais curto" (p. 83-84).

20 Cf. segundo volume do romance, capítulo 25, intitulado "Os gêmeos siameses".

21 Tristão de Alencar Araripe Jr. Raul Pompéia. O Ateneu e o romance psicológico. In: Teoria, crítica e história literária (seleção e apresentação de Alfredo Bosi). Rio de Janeiro/São Paulo. LTC/Edusp, 1978, p. 175.

$22 \mathrm{O}$ jogo antitético de opacidade e transparência constitui-se em recurso fundamental da consciência artística de Pompéia para contar a história do menino Sérgio no Ateneu. Como já observou Bosi, isto se dá sobretudo por meio de imagens referentes ao elemento da água, já nas primeiras cenas do romance; ao falar do idílio de Sérgio com dona Ema, o crítico não deixa de assinalar o retorno narrativo a imagens de luminosidade e transparência: "O horizonte diáfano e azul (a transparência, enfim) clareia os sonhos acordados do menino. A água do mar é cor de esmeralda, e vítrea a sua espessura. As nuvens cintilam, 'floresta colossal de prata'. No coradouro, entre peças de roupa irisadas de sabão, as camisas brancas, luminosas, e as saias rodadas bailando" (op. cit., p. 50).

23 Araripe Jr., op. cit., p. 176.

24 O crítico observa a esse respeito que "o gozo da felicidade, que traz o adolescente de volta ao regaço materno, exige a destruição daquele outro mundo, feito para a criança tornar-se adulto" (op. cit., p. 51).

25 Como exemplo desse enquadramento bastante questionável, cf. o ensaio de Barbara Freitag "O romance de formação brasileiro" (In: Tempo brasileiro. 118-119, jul.dez. de 1994, Rio de Janeiro, p. 163-180). No recente ensaio “As várias faces de Pompéia e $O$ Ateneu", Fábio Lucas aponta de maneira cuidadosa (porém ainda questionável) para uma dimensão da obra brasileira em que se estabeleceriam vínculos com o Bildungsroman (In: Remate de males. 15, Unicamp, 1995, p. 15-30).

Os traços que impedem a consideração de obras como $O$ Ateneu ou O Jovem Törless enquanto Bildungsroman são inúmeros, começando com o amplo recorte temporal e espacial característico deste gênero. Se é verdade que a narração de um Bildungsweg costuma englobar a etapa da infância (mas quase sempre através de breves flashbacks, e sem enfatizar o período escolar), enfocam-se, sobretudo, conflitos próprios da transição da juventude para a maturidade do herói (a rigor, apenas a velhice é excluída do processo formativo). Vale lembrar ainda que no protótipo do gênero, o romance de Goethe Os anos de aprendizagem de Wilhelm Meister, o tema da aprendizagem escolar sequer é mencionado.

26 Jean-Jacques Rousseau. Emílio ou da Educação (tradução de Sérgio Milliet). $2^{\mathrm{a}}$ ed. São Paulo, Difusão Européia do Livro, 1973, p. 264-267.

As reflexões desenvolvidas por Rousseau nesse contexto visam preservar o educando (naturalmente imbuído da "facilidade da fé cega", para usar expressão de Pompéia) das manipulações que podem decorrer da leitura de obras historiográficas, pois "muito 
falta para que os fatos descritos na história sejam a pintura exata dos mesmos fatos como ocorreram: mudam de forma na cabeça do historiador, amoldam-se a seus interesses, tomam a cor de seus preconceitos". Somente aṕ́s o $15^{\circ}$ ano de vida, aguçando-se a capacidade de discernimento e reflexão crítica, o pupilo fica autorizado a tomar contato com a historiografia.

$27 \mathrm{O}$ registro sumário das fases percorridas pela interioridade de Aristarco indicaria a seguinte seqüência: 1. Intimidação, amedrontamento diante de imenso público indistinto. 2. Recuperação da autoconfiança ao concentrar o olhar sobre um objeto (o busto ainda encoberto), que o "chamou à consciência de si mesmo". 3. Inspiração de arrebatadora retórica, o "mais espantoso chorrilho de facúndia que se tem feito correr na terra". 4. Receio advindo da expectativa do discurso de Venâncio, 0 adulador desmesurado disputando-lhe sempre "uma ponta para carregar do manto de glórias". 5. Metamorfose de Aristarco, pelo encômio de Venâncio, em bronze. 6. Sentimento de encontrar-se alienado no busto; amargando intuitivamente a concorrência desigual, arrebata a coroa de louros ao bronze, o que é interpretado como gesto de modéstia. 7. Sensação final de desgosto e insipidez: "Ruminava confusamente a tristeza daquela realidade nova - o bronze invencível".

Em $O$ Ateneu são poucas as passagens em que a reconstituição psicológica do vivido faz a perspectiva em primeira pessoa converter-se em onisciente, mas em vista destas torna-se incompreensível a afirmação de Roberto Schwarz de que "só pode ser narrado ou comentado o que esta [a criança Sérgio] experimentou”. E continua o crítico em seu estudo no mais bastante agudo: " $O$ Atheneu atende essa exigência com bastante rigor. Em coerência com a perspectiva tomada, a única interioridade que apresenta $E$ a do proprio autor" (O Atheneu. In: $A$ sereia e o desconfiado. Rio de Janeiro, 1965, p. 12-17).

28 Araripe Jr., op. cit., p. 166. Mais adiante lê-se, nessa crítica pioneira, a seguinte observação: ' $O$ ' absinto de que usou Raul Pompéia no seu romance, para produzir a unidade de efeito, foi a idéia fixa da instituição que se não define, que ataca e decompõe os indivíduos pela violência de um movimento que se não apreende" (p. 189).

29 Conforme explica Paulo Rónai, esta frase - "Não estudamos para a escola, e sim para a vida" - representa a inversão de um trecho das Epistolas em que Sêneca critica a instrução da época. Cf. Não perca o seu latim. $3^{\mathrm{a}}$ ed. Rio de Janeiro, 1980, p. 122.

Non scholae, sed morti discimus, intitula sugestivamente o escritor alemão Günter de Bruyn (1926) o capítulo de sua bela autobiografia Zwischenbilanz - Eine Jugend in Berlin (Balanço provisório - Uma jupentude em Berlim) dedicado ao seu período escolar na Alemanha hitlerista (S. Fischer Verlag, 1992, p. 101-108).

30 Ver a esse respeito as reflexões feitas no ensaio "Educação depois de Auschwitz" (In: Educação e emancipaf̧ão, tradução e prefácio de Wolfgang Leo Maar. São Paulo, 1995, p. 119-138). Em muitos pontos, as formulações de Adorno oferecem valiosos subsídios para a discussão de questões implicitamente presentes no gênero narrativo aqui enfocado. Algumas observações não poderiam ser mais claras e diretas, começando já com a frase inicial: "A exigência de que Auschwitz não se repita é a primeira de todas para a educação". Citando mais duas formulações: "A educação tem sentido unicamente como educação dirigida a uma auto-reflexão crítica" (p. 121). "O único poder efetivo contra o princípio de Auschwitz seria autonomia, para usar a 
expressão kantiana; o poder para a reflexão, a autodeterminação, a não-participação" (p. 125).

31 Katz und Maus - Eine Novelle foi publicada em 1961 e insere-se no ciclo épico conhecido como Trilogia de Danzig, ao lado dos romances Die Blechtrommel ( $O$ tambor de lata), 1959, e Hundejabre (Anos de cão), 1963. Como estes, também foi traduzida para o português: Gato e rato (tradução Rachel T. Valença). Rio de Janeiro, Editorial Labor do Brasil, 1976.

32 Numa excelente resenha da novela de Grass, Anatol Rosenfeld chama a atenção para o papel relevante que passagens ditas "obscenas", "blasfemas" etc. podem exercer em grandes obras de arte, e assim desqualifica as acusações levantadas contra a novela. A resenha "Grass e o obsceno" foi publicada originalmente no suplemento cultural do Estado de S. Paulo (24/09/1966), e encontra-se reproduzida no volume Letras germánicas, São Paulo, 1993, p. 240-248.

33 Como se depreende da oscilação pronominal nas referências a Mahlke, a novela pode ser lida, em uma de suas dimensões, como uma longa carta que o narrador, movido pelo sentimento de culpa, dirige ao amigo que provavelmente perdeu a vida cerca de quinze anos atrás. No segundo capítulo, citando mais um exemplo, o narrador lembra o papel obscuro que Mahlke desempenhava na Juventude Hitlerista, em contraste com a "fama especial - nem boa, nem má - fama lendária" de que gozava na escola: "Pelo visto, o nosso ginásio, em comparação com a mencionada organização da juventude, veio a significar para ti, com o passar do tempo, mais do que um ginásio comum - com sua tradição em parte rígida, em parte simpática, com seus coloridos bonés colegiais, com seu espírito estudantil tantas vezes invocado - pode satisfazer em matéria de expectativas como as que tu deves ter acalentado" (p. 26).

34 Numa passagem do nono capítulo, esse sistema social é codificado no "cheiro de cebola" que parece emanar de todas as casas pelas quais o eu-narrador passa a caminho do herói Mahlke. A passagem estratifica-se em várias camadas de significação, com o esboço de círculos concêntricos ligando pequenas ruas de Langfuhr (bairro de Danzig onde se localiza o ginásio Conradinum) à totalidade do Reich hitlerista, o desmascaramento do terror como componente da vida cotidiana, a extrapolação para a esfera da redação da novela: "Por isso eu devia esfregar minha máquina de escrever superficialmente com sumo de cebola para dar a ela e a mim uma idéia do cheiro de cebola que naqueles anos empesteava toda a Alemanha, a Prússia Ocidental, Langfuhr, a Osterzeile e a Westerzeile, abafando o cheiro de cadáver predominante".

Resumo - Obras que tematizam o choque do adolescente ou pré-adolescente com o meio hostil da escola constituem um tipo narrativo com expressiva representação na literatura ocidental. O presente ensaio procede inicialmente a um esboço da constelação temática característica dessas "histórias de internos ou alunos". Em seguida busca concretizá-lo - e ao mesmo tempo determinar as especificidades desse gênero literário por meio de uma comparação entre os romances $O$ Ateneu (1888) e As atribulações do pupilo Torless (1906). Nessas obras de juventude, fortemente autobiográficas, Raul Pompéia e Robert Musil lograram incorporar às narrativas sobre a traumática experiência dos meninos Sérgio e Törless, no microcosmo da escola, traços de comportamento e mentalidade que se objetivaram algumas décadas depois em realidade histórica. Apon- 
ta-se ainda, de maneira sumária, para a possibilidade de desdobrar o estudo comparativo com a inclusão da novela Gato e rato (1961), em que Günter Grass faz da relação conflitiva do adolescente Joachim Mahlke com o seu ginásio o ponto de fuga de uma representação radicalmente crítica da sociedade nacional-socialista. $O$ final especulativo do ensaio procura descortinar uma vista para as questões ideológicas, pedagógicas e existenciais implicadas nessas pequenas narrativas que, aparentemente, tratam apenas de um drama mais ou menos comum do período escolar.

Abstract - There are a number of important works that analyse the clash between adolescents or pre-adolescents and the hostile school environment in Western literature. The essay initially outlines the themes that characterise these "school stories". It then defines the characteristics of these themes and at the same time tries to determine the specificities of this literary genre through a comparison between the novels $O$ Ateneu (1888) and Die Verwirrungen des Zöglings Törless (1906). In these strongly autobiographical works, Raul Pompéia and Robert Musil incorporate traces of behaviour and types of mentality that became evident in the historical reality some decades later into their narratives about the traumatic school experiences of Sérgio and Törless. This essay also extends the comparative study, though in a succinct way, to the "Novelle" Katz und Maus (1961), where Günter Grass makes the clash between the teenager Joachim Mahlke and his school a starting point for a radical criticism of the national socialist society. The speculative end of this essay tries to give a general view of the ideological, pedagogical and existential depths of these short narratives which apparently deal only with the ordinary drama of school life.

Marcus Vinicius Mazzari é doutor em germanística pela Universidade Livre de Berlim e professor de teoria literária e literatura comparada da USP. 